\title{
The Future Potential of Horticultural Plant Discovery, Improvement, and Production in Nepal
}

\author{
Michael A. Schnelle ${ }^{1}$ \\ Extension Specialist, Department of Horticulture and Landscape Architecture, Oklahoma State University, \\ Stillwater, OK 74078-6027
}

Additional index words. Himalayas, medicinal plants, ornamentals, food crops

\begin{abstract}
The country of Nepal is geographically variable and thus has significant diversity in its native flora. Because of physical and social barriers that still exist, many indigenous plant materials have yet to be adequately screened for their uses not only within Nepal, but outside its borders. Maximum production of horticultural crops in Nepal will require improved water distribution, adequate pest control, and consideration of social/demographic issues.
\end{abstract}

Nepal is $147,181 \mathrm{~km}^{2}$ in size bordered by China and India. Nepal extends along the Himalayan range between the latitudes of $26^{\circ} 22^{\prime} \mathrm{N}$ and $30^{\circ} 27^{\prime} \mathrm{N}$ and longitudes of $80^{\circ} 04^{\prime} \mathrm{E}$ and $88^{\circ} 12^{\prime} \mathrm{E}$. The country has three physiographic regions having mountains in the north, hills in the middle, and the Terai in the south bordering India. Approximately $86 \%$ of the area is occupied by mountains and hills with the Terai (flat terrain) accounting for the remaining $14 \%$ of land. Farmers cultivate crops up to $4200 \mathrm{~m}$ with altitude peaking at $8848 \mathrm{~m}$ in the north. From a botanical viewpoint, Nepal forms a transition zone between flora of the Western Himalaya and the Eastern Himalaya. The Tibetan Plateau also has unique species from the north and tropical species of the lowland plains from the Gangetic plains of India into Indochina. The Himalayan range contributes to the diversity of taxa and has provided barriers as well as corridors that plants were able to negotiate through during the ice ages (Nepal and Its Plants, 2010).

Nepal's gross domestic product (GDP) was $\$ 12.6$ billion when accounted for in U.S. dollars (Nepal Microfinance Summit, 2009). Agriculture represents one-third of the GDP. Three-fourths of the population is supported by agriculture. The per-capita income for 2009 was reported at \$427 U.S. (World Bank) (U.S. Department of State Diplomacy in Action, 2010). The major supplier of goods is India with Nepal experiencing a trade deficit of $\$ 3.89$ billion (U.S.) in 2010. Based on national calorie/GNP criteria, $\approx 55 \%$ of the population is below the poverty line of $\$ 1.25$ (U.S.) per day.

Regarding land, $25 \%$ is cultivable, $33 \%$ is forested with the balance mountainous and difficult to cultivate. Approximately $90 \%$ of Nepalese rely on subsistence agriculture with plants serving a critical role as arable crops, fodder, fruit, vegetables, medicines, etc.

\footnotetext{
Received for publication 13 Dec. 2011. Accepted for publication 6 Mar. 2012.

This paper was part of the workshop "Asia's Indigenous Horticultural Crops" held 26 July 2009 at the ASHS Conference, St. Louis, MO, and sponsored by the Working Group of Asian Horticulture (WGAH).

${ }^{1}$ To whom reprint requests should be addressed; e-mail mike.schnelle@okstate.edu.
}

\section{ORNAMENTAL SPECIES}

Concerning ornamental plant production, a plethora of ornamentally significant species are endemic to Nepal. The Floriculture Association Nepal (FAN) exists to support overall development of the floriculture subsector of the country. Participation in trade fairs, market research and analysis, operation of wholesale outlets, and other endeavors is underway as a result of the advent of FAN (Nepal and Its Plants, 2010). The U.S. nursery and floriculture industries could benefit by securing widespread germplasm of Nepal's ornamental species for enhanced cold-hardiness and other potential benefits in U.S. locations. Some commercially available Nepalese species are Lily of Nepal (Lilium nepalense), palm (Trachycarpus spp.), and a plethora of others already enjoyed outside Nepal's borders. The genus Rhododendron, for example, alone has $\approx 30$ indigenous species in Nepal (Jha et al., 1996). Kunwar and Bussmann (2006) report 36 Ficus species indigenous to Nepal. Great potential seemingly exists for cut flower production, which is currently underway in Kathmandu but potentially feasible throughout Nepal. Growers currently are cultivating calla lily (Zantedeschia aethiopica), carnation (Dianthus caryophyllus), gerbera daisy (Gerbera jamesonii), gladiolus (Gladiolus $\times$ hybrids), lycoris (Lycoris spp.), tuberose (Polianthes tuberose), and a plethora of orchid species (Shrestha, 2003). Although orchids have been routinely exported to Japan and Singapore, Nepal still has significantly untapped potential in exports of cut flowers of chrysanthemum (Dendranthema $\times$ grandiflorum), gerbera daisy (G. jamesonii), gladiolus (Gladiolus $\times$ hybrids), roses (Rosa spp.), etc., to India (The Hindu, 2005). A minimum of 230 families of flowering plants can be found in Nepal and are consequently of value for trialing purposes, breeding programs, etc., throughout temperate and subtropical areas of the world (eFlora, 2011). The Flora of Nepal project has yet to come to fruition but would more adequately reflect the rich germplasm of the country.

\section{EDIBLE SPECIES}

Many districts within Nepal reported a moderate to high level of food insecurity in 2010 (Relief Web, 2010). Given that some communities are nearly $100 \%$ vegetarian, this becomes an even more critical horticultural challenge to address. Production losses occur to a number of natural phenomenon including but not limited to drought, heavy snowfall, hailstorm, flood, and landslide disasters (Relief Web, 2010). Some areas such as Humla have reportedly faced food insecurity for up to $75 \%$ of its population. With an estimated annual population growth of $2.132 \%$ per year, more food insecurity can be expected. According to a current Ministry of Agriculture and Cooperative report (Agro News, 2010), production of vegetables increased by $9.0 \%$ to $3,001,000 \mathrm{t}$, whereas fruit production increased by $3.0 \%$ to $705,000 \mathrm{t}$. Potatoes individually monitored increased from 2.42 million $t$ to 2.45 million $t$. According to a recent Nepal Vegetable Crops Survey 2009-2010, 69.3\% of households were involved in some form of vegetable farming. Seventeen percent of the total vegetable farmers are female but only $37 \%$ of people selling the produce are females. Furthermore, surveyors found that 2,820,527 t produce was generated from 232,295 ha of land (fiscal year 2009-2010) (Himalayan News Service, 2010). Depending on the region of Nepal, various cultural taboos and socioeconomic factors influence vegetable production and consumption. Some of the population claims that vegetables should not be consumed if the person has an illness. Lactating mothers are sometimes advised to avoid green vegetables lest they harm the mother and her infant. Some people feel a loss of dignity if they grow and sell vegetables. Lastly, vegetables are credited for adding taste and variety but are not necessarily regarded as being rich in nutrients (Thapa and Paudyal, 2009). Other challenges starting to be overcome are cultural ones such as growers coping with high rainfalls and proper drainage. Sensitive crops such as cabbage (Brassica oleracea) and cauliflower (Brassica oleracea var. botrytis) are routinely planted on raised beds to ensure good aeration and to avoid root rot and other problems. Some growers are using synthetic pesticides indiscriminately with little integrated pest management being practiced to date. Examples of other common vegetables cultivated in Nepal are sweet corn (Zea mays var. rugosa), potato (Solanum tuberosum), spinach (Spinacea oleracea), eggplant (Solanum melongena), tomato (Lycopersicon esculentum), 
asparagus (Asparagus officinalis), cucumber (Cucumis sativus), long beans (Vigna unguiculata), pumpkin (Cucurbita maxima), cabbage (B. oleracea), and cauliflower (B. oleracea var. botrytis). Farmers have recently been encouraged to grow off-season vegetables to improve and even out otherwise low-income months of the year but also improve food supply and reduce dependency on nearby India (Ogonowski, 2008). Farmers in the hills of Nepal, during the rainy season, have an advantage over producers in India that lie in flat, poorly drained areas. These Nepali farmers can meet a need where the supply of Indian vegetables at that time is otherwise low and prices high. Other opportunities for Nepal's producers are in Bangladesh and Gulf countries, although some challenges have occurred for Nepali farmers to fully comply with the sanitary and phytosanitary requirements of the Indian Plant Quarantine Office at the India-Nepal border (Ogonowski, 2008). The Livelihood and Income Generation Component of USAID's Flood Recovery Program has shown many farmers are no longer purchasing produce from India and then reselling it in Nepal but rather are growing and selling produce within Nepal's borders and at greater profits (USAID, 2010).

Production losses of up to $30 \%$ continue to be realized mainly as a result of insects and diseases that are not being adequately managed/addressed. Besides pest control, weeds are managed by hand removal or by mulching with little herbicides used or available to date. Organic manure, either composted from locally available organic materials or farm manures, are often used in lieu of synthetic fertilizers. Nepali farmers also use wood ash, cattle urine, weeds pulled from planting areas, leguminous crops, and other means to fertilize their crops.

\section{FRUIT PRODUCTION}

A number of common as well as geographically specific fruit crops are grown. High-chilling and low-chilling cultivars of apple (Malus spp.) are grown throughout Nepal. Crabapple (M. baccata) is often germinated and used for growing rootstocks. The Malling series of apple rootstocks have also been introduced to a few horticultural operations in the country. Many of the apples are grown at 1800 to $2800 \mathrm{~m}$ above sealevel (m.a.s.1.), although some low chilling cultivars (less than $1000 \mathrm{~h}$ ) are being cultivated at 1200 m.a.s.l. Some apple farmers have been forced to grow their crops in higher elevations given that warming temperatures have resulted in their fruits being riddled by pests (IPS News, 2010). Besides apple, both European pear (Pyrus communis) and Asian pear (Pyrus pyrifolia) are grown often grafted on a wild rootstock (Pyrus pashia). Over 40 cultivars of peach (Prunus persica) have been introduced to Nepal, grafted on a wild cultivar of peach in Nepal (Prunus spp.) that also serves as a rootstock for nectarine (Prunus persica var. nectarina) and almond (Prunus dulcis). Apricot (Prunus armeniaca) introductions have not been as successful to date. Many of the farmers intercrop these stone fruits with vegetables. Most of the deciduous fruit crops are grown in remote areas of Nepal without access to roads and without access to storage or processing facilities (Devkota, 1999). Consequently, highly perishable crops such as peach (Prunus persica) are often sold by farmers at a nominal price given the aforementioned challenges. In addition to stone fruits, subtropical fruit crops commonly cultivated in Nepal include but are not limited to lychee (Litchi chinensis), mango (Mangifera indica), banana (Musa spp.) guava (Psidium guajava), papaya (Carica papaya), sweet oranges (Citrus sinensis), mandarin (Citrus reticulata), and lime (Citrus aurantifolia). Although greater fruit production is needed for a growing population and to be less dependent on imports from India, a number of constraints such as an inadequate extension system, low priority for fruit research, little training in fruit production, etc., greatly limit fruit production expansion. In addition to cultivated fruits grown in Nepal, 107 indigenous fruit and nut species have been reported (Joshi et al., 2007). Many of Nepal's endemic edible crops have yet to be commercially explored. Despite considerable efforts in fruit production, India is still relied on for a significant amount of fruit consumed in Nepal.

\section{MEDICINAL SPECIES}

Over 1000 plants have been used for medicinal purposes in Nepal (Nepal and Its Plants, 2010) with steroid-yielding plants such as Dioscorea deltoidea and D. prazeri both yielding diosgenin. These species are two of many promising indigenous phytoceuticals. Diosgenin once converted into 16dehydropregnenolon acetate can be used as an a.i. in manufacturing contraceptives, sex hormones, steroid drugs, etc. A number of Solanum species also yield diosgenin (Singh and Kaushal, 2007). Many of the aforementioned medicinal plants are still wild, collected with an acute need for cultivating them for consistent quality and sustainable supply of raw materials. Related plants and related uses such as aromatic species, oil-yielding crops, etc., need further exploration as well. Over 170 plant species with dye-yielding properties are grown in Nepal (Shrestha, 1994). Cotton, silk, leather, and wool have all been dyed by Nepal's botanical products.

\section{ADVANCES AND CHALLENGES}

The first tissue culture efforts were initiated in 1976 at the National Herbarium and Plant Research Laboratory in Godawari. Since then, a number of plants have undergone clonal propagation including at least 30 species of orchids, hardwood trees, medicinal plants, ornamentals species such as gerbera daisy and others. With breakthroughs including virus-free potato seed, biotechnological efforts will increase to meet the demand for medicine, food supply, etc. (Biotechnology in Nepal, 2010). Despite high rainfall in many areas of Nepal, farmers in the mountainous areas often fail to collect enough water for basic needs including irrigation of crops. Multiple use water systems (MUS), using gravity and a system of pipes carrying spring water, have been implemented by the government to help alleviate water shortages and provide $500 \mathrm{~L}$ of water a day for irrigation purposes now making crop production in these areas more feasible (Practical Action Publishing, 2011). Furthermore, riverbank farming is being investigated where producers are cultivating vegetables in the riverbanks that were thought to be landless in the past (Practical Action Publishing, 2011). This practice has also led to bartering with other growers for their wheat (Triticum aestivum) as an equal exchange. With the advent of microfinancing (Nepal Microfinance Summit, 2009), many farmers may find this as a viable option to farm with the assistance of relatively small amounts of loaned capital. Organic horticultural production is often carried out but by default. Much of the produce cannot be properly certified to satisfy international standards and price premiums. Furthermore, comprehensive use of water resources has not yet come to fruition. Less than $40 \%$ of cultivable land is irrigated while there is potential to reach two-thirds of such land.

\section{CONCLUSIONS}

A number of plant expeditions have been conducted in Nepal by horticultural explorers around the world (Lancaster, 1995). For example, genera critical to the U.S. ornamentals industry and abroad were collected such as Viburnum, Jasminum, Berberis, Primula, Cotoneaster, Deutzia, Clematis, Euonymus, Acer, and Arisaema in 2001 (Edinburgh Nepal Expedition in 2001). Approximately 6000 flowering and another 4000 non-flowering plants are thought to exist in Nepal. With at least 246 flowering species endemic $(\approx 5 \%$ endemic) to Nepal (Nepal and Its Plants, 2010), the future is promising for continued horticultural exploration of the region. Nepal is considered one of the richest depositories of plant materials in the world. With deforestation, current land use, and lack of protocols for managing indigenous species, it is critical that Nepal's flora be immediately mapped and protected before extinctions commence. Reviews of plant genetic resources of Nepal can be found in Jha et al. (1996). Many past expeditions have not extended much beyond the capital of Katmandu. There are a number of remote and hard-toaccess areas within Nepal that have yet to be scrutinized for potentially valuable plants for commerce. Although the catalog and enumeration of the flowering and non-flowering plant materials of Nepal have been noted, there still is a void for a comprehensive flora of Nepal detailing identification keys, representative illustrations, description, local names, local uses, etc. (The Flora and Vegetation of Nepal, 1999). These valuable natural resources are in critical need of being documented before they are lost or disappear (Acharya and 
Acharya, 2009). Better horticultural practices in Nepal could expedite or otherwise slowly lead to a transition from subsistence farming to a commercial economy.

\section{Literature Cited}

Acharya, K.P. and R. Acharya. 2009. Indigenous knowledge on miscellaneous uses of plants by the People Parroha VDC, Rupandehi District. Central Nepal. Ethnobotanical Leaflets 13:1295-1301.

Agro News. 2010. 3 Mar. 2012. <http://www.moac. gov.np>.

Biotechnology in Nepal. 2010. 16 May 2011.<http:// technologyofbiology.blogspot.com/2010/02/ present-status-of-biotechnology-in.html>.

Devkota, L.N. 1999. Deciduous fruit production in Nepal. 13 May 2011.<http://www.fao.org/ docrep/004/ab985e/ab985e09.htm>.

eFlora. 2011. 2 Mar. 2012. <http:www.efloras.org/ browse.aspx?flora_id $=110>$.

Himalyan News Service. 2010. 14 May 2011. <http: //www.thehimalyantimes.com/fullNews.php? headline $=$ Commercial + vegetable + farming $>$.

IPS News. 2010. 14 May 2011. <http://ipsnews. net $/$ news.asp?idnews $=53044>$. Accessed.

Jha, P.K., K.K. Shrestha, M.P. Upadhyay, D.P. Stimart, and D.M. Spooner. 1996. Plant genetic resources of Nepal: A guide for plant breeders of agricultural, horticultural and forestry crops. Euphytica 87:189-210.

Joshi, N., K. Kehlenbeck, and B.L. Maass. 2007. Traditional neglected vegetables of Nepal: Their sustainable utilization. Econ. Bot. 24: 241-278.

Kunwar, R. and R.W. Bussmann. 2006. Ficus (Fig) species in Nepal: A review of diversity and indigenous uses. Lyonia 11:85-97.

Lancaster, R. 1995. A plantsman in Nepal. Antique Collectors' Club Publishing, Woodbrige, Suffolk, UK.

Nepal agricultural policy and strategies for poverty alleviation and food security. June 2003. NEP/ 99/023:SPPD Report.

Nepal and Its Plants. 2010. 3 May 2011. <http:// www.nepalflowers.com/blog/2010/11/nepal-andits-plants/>.

Nepal Microfinance Summit. 2009. http://www. microcapital.org/microfinance-event-the-nepalmicrofiance-summit-presentation. 16 May 2011. $<$ http://www.sos-arsenic.net/english/homegarden/ nepal.html>.

Ogonowski, J. USAID: Asia and Near East farmer to farmer final report. Sept. 2008 (15).

Practical Action Publishing. 2011. <http:// practicalaction.org/water-and-sanitation/multiuser-water-systems>.
Relief Web. 2010. Nepal: Food security bulletin 28, Aug. 2010. 16 May 2011. <http://reliefweb. int/node/363802>.

Shrestha, B. 1994. Dye-yielding plants of Nepal. Research Centre for Applied Science and Technology, Tribhavan University Press.

Shrestha, S. 2003. Floriculture trade fair. 2 Mar. 2012. <http://Webbuild.knu.ac./kr/ iatc/report/ Nepal.doc $>$.

Singh, K.N. and R. Kaushal. 2007. Comprehensive notes on commercial utilization, characteristics and status of steroid yielding plants in India. Ethnobotanical Leaflets 11:45-51.

Thapa, G.B. and D. Paudyal. 2009. 4 May 2011. $<$ http://www.avdrc.org/pdf/dynamics/Nepal. pdf $>$.

The Flora and Vegetation of Nepal. 1999. 14 May 2011.<http://www.sos-arsenic-net/english/ homegarden/nepal.html $>$.

The Hindu. 2005. 26 Feb. 2012. <http://www.hindu. com/2005/01/29/stories/2005012911980300. htm>.

USAID. 2010. 16 May 2011. <http://nepal.usaid. gov/newsroom/telling-our-story/economy-growthand-education.html $>$.

U.S. Department of State Diplomacy in Action. Dec. 2010. 15 May 2011. <http:www.state.gov/r/pa/ei/ bgn/5283.htm>. 